\title{
Proverb as a Tool of Persuasion in Political Discourse (on the Material of Georgian and French languages)
}

\author{
Bela Glonti \\ School of Arts and Sciences, Ilia State University, Tbilisi, Georgia; \\ The Francophone Regional Doctoral College of Central and Eastern Europe in the Humanities (CODFREURCOR), \\ Georgia
}

\begin{abstract}
Our study deals with the use of proverbs as a tool of persuasion in political discourse. Within this study we have studied and analyzed the texts of Georgian and French political articles, speeches and proverbs used therein. The analysis revealed that the proverbs found and used by us in the French discourses were not only of French origin. Also, most of the proverbs found in the French discourses were used as titles of the articles. As for the Georgian proverbs, they consisted mainly of popular proverbs well known to the Georgian public. Georgia proverbs have rarely been cited as an article title. According to the general conclusion, the use of proverbs as a tool of persuasion in the political discourse by the politicians of both countries is quite relevant. It is effective when it is persuasive and at the same time causes an emotional reaction. Quoting the proverbs, the politicians base their thinking on positions. The proverb is one of the key argumentative techniques.
\end{abstract}

Index Terms - proverb, translation, culture, argumentation

\section{INTRODUCTION}

The article is concerned with a proverb, as a tool of persuasion in Georgian and French political discourse. In the beginning, we'll review the conception of a proverb and try to pick out a working definition acceptable for us from several existing ones.

We will analyze and identify the impact of the different socio-cultural environments through comparative study. Apart from this, we will try to identify the use of proverbs determined by the aforementioned impact as a tool of persuasion in political discourse.

As a basis, we will use the material from both printed and electronic Georgian and French publications, where there are published interviews of politicians, as well as politicians' and political scientists' assessments of current political, economic, social and cultural events in the country. The basis also includes political speeches.

The novelty of our study is the fact that the use of the argumentative technique of proverb hasn't been studied yet with the use of comparative methodology according to Georgian and French materials, especially with the materials of political discourse.

Proverb is a quite complex and multifaceted phenomenon. Perhaps that was the reason that virtually no verbal form has been a subject of so many studies as a proverb is. In particular, it is studied in the fields of folklore, linguistics, sociology, ethnography, pedagogics, psychology and psychiatry.

\section{LITERATURE REVIEW}

It should be noted that our study issue, i.e. topic of proverb, has been the subject of interest since the middle of the XIX century, but its permanent scientific study began in the second half of the XX century. The discipline which recognizes proverb as a main object of the study emerged exactly this period of time. This is paremiology. Paremiology is interested in collecting, analyzing and sorting of proverbs, wise expressions said by people that were orally propagated. Paremiology combines all proverb related things, everything that concerns the study of proverbs.

The most important work in paremiology belongs to Archie Taylor, the American linguist, "The proverb", published in 1931 and even today it is considered as an introduction to paremiology. Important works in paremiology were also written by Matti Kuusi, "Towards an international type-system of Proverbs" (1972). Kuusi is also a founder and publisher of the first international scientific journal, "Proverbium". Wolfgang Mieder is also considered to be the founder of paremiology. His works published in various years are still in the center of attention of paremiologists as one of the basic theoretical materials, "Proverbs are never out of season: popular wisdom in the modern Age, published in 1983. Contemporary works in paremiology "Proverbes et formes proverbiales: valeur évidentielle et argumentative" (1994), "La parole proverbiale" belong to Jean-Claude Anscombre. There are also "Sur le sens des proverbes" (2000) 
by Georges Kleiber and "Sens figé: idiomes et proverbes" by Irène Tamba, Wolfgang Mieder's "A handbook" (2004), "Behold the proverbs of a people: proverbial wisdom in culture, literature, and politics" (2014).

In spite of the time limitations of study and the abundance of scientific papers there is no uniform definition of the proverb. After discussing various definitions of proverbs in the abovementioned papers, we have developed the following definition of the proverb: a proverb is a result of collective awareness, a verbal form existing in all languages and, unlike all other large or small verbal forms, it has an indigenous, specific content, structure and perception. Proverb draws a picture of regular events of the universe figuratively. In some proverbs an icon is sharply metaphorical, it is less metaphorical in other ones. A sentence is the lower level of the proverbial structure. Proverb determines knowledge accumulated by humans in the process of assimilation and differentiation of the world and in the same way "revives" it in a particular communication context.

Despite the simple and refined form understandable for everybody at first sight, proverb is paroemias with rather complicated specifics. It is a universal phenomenon having been practiced been fixed apparently for centuries in a solid verbal form in every language and it always responds to the demands of awareness with its function.

Proverb is a formula modeled like a concept in the mentality of nation, which is informative in the context of differential psychology of nations. The proverb gives us an idea of the peculiarities of national point of view of people speaking this language. This approach enables the identification of different ethnic cultures.

Virtually paremiology recognizes unambiguously that the semantic structure of proverb consists of thematic-logical combinations (although the approaches differ from each other (Krikman, 1998; Barley, 1972).

At the end of the $20^{\text {th }}$ century V. Mieder, an author of the famous book "Proverb are never out of Season" (1983), gave a positive assessment of paremiology from retrospective study positions. According to him, paremiologists have made an important contribution to the study of proverbs, providing a solid foundation which the future paremiology can continue to build on.

Whereas our basis consists of proverbs used in political discourses, we need to review political discourse briefly. The most important work on political discourse belongs to Patrick Charaudeau's "Political discourse, masks of power. This work is an excellent example of interdisciplinary study on political discourse. According to Charaudeau (2005), communication situation is very important for political discourse, because "it is the communication situation giving a political character to the discourse and not the content of the discourse" (p. 30). There are other significant works in this field, such as Ruth Amossy's "Political discourse", Baylon's "Sociolinguistics". According to Ruth Amossy, "political discourse is any kind of discourse involving a discussion about the social arrangement."(p.247) Baylon argues that discourse is political when it is uttered by a politician for political purposes.(p.93)

\section{METHOD}

The study methodology of our article will be interdisciplinary and comparative. This will be a linguistic study covering sociocultural, linguocultural, ethnological and pure cultural aspects.

Accordingly, we are studying this issue quite differently - we discuss proverbs created by nations using the French language, having French culture and traditions, on the one hand, and, on the other hand, we discuss proverbs created by nations using Georgian language, having Georgian culture and traditions. We will analyze two completely different socio cultural environments determining the politician's choice to use a particular proverb as a tool of persuasion.

\section{RESULTS}

We'll begin the study of the basis by illustrating the use of common argumentative techniques (using specific examples from both Georgian and French press) being used by politicians of both countries to make their discourses effective and successful. However, proverbs are used with different intensity in Georgian and French discourses as one of the supporting argumentative techniques for persuading listeners/readers. Also from the socio-cultural point of view, in their discourses the politicians of the two countries have used the types and themes corresponding to the sociocultural, historical-cultural, ethno-cultural background of each country, and thus are easily understandable by the majority of audience.

Let's discuss specific examples and identify similarities among them. We have analyzed articles both in printed and electronic media, as well as video recordings of TV shows. We have identified that the proverbs which were obtained from political discourse (we have found, discussed and analyzed 41 French discourses and 54 Georgian discourses, some of which are given in the article), basically had been used in France by oppositionist politicians for strengthening their ideas.

For example: All talk and no action! (Grand diseux, petit faiseux. fr.).

Promising a lot, giving a little.

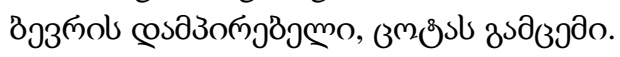

Everything with words, nothings with deed.

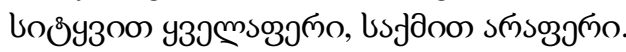

The abovementioned proverb was used by Laurent Fabius, the former Prime Minister of France, during the talk about President Nicolas Sarkozy on "France 5", in the TV show "Ripostes" on September 25, 2008. The former Prime 
Minister expressed dissatisfaction toward the President's numerous unfulfilled promises, adding that he was from Normandy and used Norman aforementioned proverb as one of the strong arguments for supporting his views.

The proverb is a solid argument as it is the result of collective awareness. It does not have a single author whom the society trusts or not. In most cases, the proverb expresses the public truth that is shared by a large part of society.

This proves once again that proverb has a great reliability and credibility in the reader, on the other hand, the usage of proverbs by politicians causes an effective and emotional response. The origin of this proverb is Norman. That's why it is correctly chosen to be used by the Norman politician. This proverb is seen as a key tool of persuasion and one of the basic argumentative techniques in political discourse.

Proverbs in Georgian discourses are often used not only by oppositionists but also by senior officials of the government, which indicates that proverbs play a major role in shaping the voters' opinions and at the same time increase their credibility with politicians. While assessing the possible amendments to the Labor Code the Speaker of Parliament, Archil Talakvadze used the proverb known as "Measure thrice and cut once". He used this proverb after expressing the position of the Speaker of the Parliament and the ruling party that important laws should be adopted after the impact assessment and communication with the relevant sectors. In this case, the use of proverbs as an argumentative technique to influence the audience is also effective. The author of the article has mentioned the proverb in the title of the article, which also confirms the high credibility of the proverb in Georgian society.

In Georgian discourses, oppositionist politicians don't use proverbs rarely as one of the effective tool of persuasion. For the instance, we can mention the discourse of Kakha Kukava, an oppositionist deputy who talked about the possible participation of his party Free Georgia in the elections in the broadcast of "Moambe" of Georgian First Channel. Oppositionist deputy expresses his supposition that if a sufficient number of people take part in the elections the ruling party Georgian Dream and the former ruling party National Movement will have no chance of winning. According to this his no so famous party is likely to win. His opinion is supported by old Georgian proverb, "Nothing ventured, nothing gained". This proverb was Kukava's response to the broadcaster's question about his program minimum in the elections because he received only $1.25 \%$ of votes in the local self-government elections.

It is also very interesting to discuss the proverbs used in the assessment of political events. Interpressnews interviewed Professor of International Law, academician Levan Aleksidze, about the problems of investigating the August war of 2008. In assessing these events Aleksidze notes that it is unacceptable to accuse former President of Georgia Mikheil Saakashvili of having European friends support and seek nepotism in this fact. These people are the ones who are helping Georgia get closer to Europe and ruining the relationship with them will do nothing for the country. Levan Aleksidze uses a famous Georgian proverb that sounds as follows, "You should not spit in the well from which you have to drink water" (Let every man speak well of the bridge that carries him over). Aleksidze says that politics needs more prudence and calls on this proverb to strengthen his opinion and get much more reliability and credibility as a general truth shared by people.

Georgian Discourses:

It is very interesting quite long-running discourse of the former Georgian President Mikheil Saakashvili during his speech in parliament during his presidency. He emphasized the unity of the party noting that his opponents had not broken the unity of him and his party National Movement, and were trying to apply pressure on party members at that time. He used the proverb "Power is in the unity" to create more reliability and credibility, which means that they can't break us (article published by the Information Analytical Agency on December 23, 2012). The author of the article has published the proverb as a title of the article.

On November 17, 2016, Dimitri Kumsishvili, the First Deputy Prime Minister of Georgia and the Minister of Economy and Sustainable Development, responded with a proverb to a question posed by a journalist about governmental changes. Journalists were interested in the new convocation of the parliament and possible governmental changes. Kumsishvili said the Georgian proverb "Easter and tomorrow" and then added that it would be exactly the next day and it would be better to wait for it. Using this proverb, Dimitri Kumsishvili satisfied the interest of a large part of the society about the governmental changes by using the proverb, which was originated from the society itself. This tool of persuasion is so credible that it reflects not only Dimitri Kumsishvili's personal opinion but it is shared and accepted by the large part of the society.

There are also very important discourses of Georgian politicians. Bidzina Ivanishvili the former Prime Minister of Georgia, uses a proverb while assessing the situation occurred after Tbilisi Zoo tragedy of June 13, 2015, caused by the flood. "Some grief is beneficial" - says the former Prime Minister about the situation occurred. According to him, he never liked the location of the former zoo. After the disaster it was necessary to move the zoo to another place. Bidzina Ivanishvili used this proverb to strengthen his opinions and cause an emotional influence.

We also found another discourse of Bidzina Ivanishvili, in which he used this proverb "Some grief is beneficial" once again. This is the discourse dated from November 27, 2019 in which the ex PM Bidzina Ivanishvili assesses current events. In the broadcast of TV Imedi he underlines that despite of the fact that all promises given have not been fulfilled the development of the country must be continued. We do not always have a choice between good and better, bad and worse. We have managed to mobilize, I have been very active and have not disband the team. The breakdown of the majority would be tragic for this country. Imagine, we have kept a stable majority, and I love the saying that 
"Some grief is beneficial". Of course it was bad as it happened, but we have to make versatile conclusions from this and carry on the stable development of the country.

This proverb is quite popular in Georgian society and its meaning is well known to the great part of the society. This is exactly what is taken into account by current or former politicians, including Bidzina Ivanishvili, while using proverbs to strengthen their opinions. In such way they make their discourses more credible and persuasive. They also create high emotional background.

On September 28, 2012, David Bakradze, the Number First of the list of the party National Movement, the Speaker of the Parliament of Georgia, addressed the supporters of the ruling party:

"All Georgia, all generations are gathered. I remind the proverb 'Unity is strength' . Yes, we are strong. This unity awaits to be tested. We have to make a choice in 3 days, the way where Georgia will go..."

While producing the most important discourse, which was uttered in the final part of the pre-election period, David Bakradze used the phrase "Unity is strength". The abovementioned proverb causes quite emotional background in the Georgian society. This proverb underlines the fact that everything can be achieved by the unity and the enemies, both internal and external ones, cannot damage us. The fact that David Bakradze's discourse and thoughts are strengthened by this proverb is not accidental. The politician understands the importance of winning over the masses, winning their hearts and getting their support in the decisive stage, pre-election period and in order to manage this he builds up an emotional discourse and uses the proverb to provide more sensitivity and persuasion.

Mamuka Katsitadze, one of the leaders of the New Rights Party, called shameful the speech of Sozar Subari having been telecasted in the Caucasia TV on May 11 (2011). According to Katsitadze: "Sozar Subari's limited ability to analyze does not allow him to make any other conclusions and he thinks that when two politicians meet they must necessarily talk about money".

"Irakli Alasania was a high-ranking diplomat; he used to meet Lavrov (Sergey Lavrov, Russia's foreign minister) and other world class politicians. He still meets politicians. Sozar Subari failed to strengthen his arguments regarding Alasania's pro-Russianism. I will simply say that I remembered one proverb: "Argue on one side of the river and stay tuned on the other side". The politicians who criticize Irakli Alasania are like this".

The proverb used by Mamuka Katsitadze, "Argue on one side of the river and stay tuned on the other side" had been chosen correctly according to the current political situation. Against the background of strongly criticizing members of the opposing ruling party by Mamuka Katsitadze's New Rights Party, they got retaliatory criticism from the ruling party accusing its supporter Irakli Alasania of being pro-Russian. Mamuka Katsitadze adapted this proverb to the current situation very well and chose the right one to support his point of view.

Proverbs used in French discourses:

La victoire a cent pères, mais la défaite est orpheline - Victory has a hundred fathers, defeat is an orphan.

The journalist reviews the current political processes in the country in the article published in the magazine "Revue des deux mondes" (May 12, 2017). They include the resignation of President François Hollande that is regarded as a serious psychological challenge for him. The concession of power derives some problems for almost all officials, and François Hollande is not an exception in this case. The journalist uses the proverb "Victory has a hundred fathers, defeat is an orphan". The journalist tries to strengthen the idea that after his resignation, François Hollande would be less acceptable in different circles than he was during the time of his presidency.

In the interview with "Focus" (September 15, 1997) Jacques Chirac, a former President of France, talks about political and social issues. Summing up the quite long-lasting interview, Jacques Chirac cites the proverb to strengthen his conclusion. Though the French president has used not a French proverb but a Chinese one and he has even emphasized on it.

Comme dit le proverbe chinois: "ce n'est pas la richesse qui manque dans le monde, c'est le partage." "It is not the wealth that is lacking in the world, it is the sharing". Jacques Chirac responded to the global financial crisis and somehow made a conclusion about it.

In political discourses it is quite relevant to use the authority of competent, well-known public figures. However, naming one and the same authority in front of the one audience may strengthen the argument, while in front of the other audience it may, on the contrary, interfere with the audience's opinion of the argumentator. That's why politicians, and in this case Jacques Chirac, the President of France of that time uses proverbs as a more credible argument. Because, as we have already mentioned, the proverb has high reliability in society and reflects the widespread truth.

In the telecast of 21 March, 1997 Jacques Chirac, then President of France, talks about the reasons having caused the dissolution of National Assembly and repeated parliamentary election. The President underlines the fact that the power belongs to people and precisely they must express their position through voting. Jacques Chirac emphasizes the unity by which can be achieved everything. He also mentions Europe. Even though there are confrontations in Europe as well, mostly it has been associated with peace during the past half century - the president admits. In today's fast-changing world, Europe will bring new opportunities and secure future for us (France), because Europe is the union and "Unity is strength".

In this case, French President Jacques Chirac used the proverb "Unity is strength" (L'union fait la force) to achieve the highest quality of thought adequacy and understanding. This is a well-known way of calling on the authority. In the 
final part of his speech, the President added the proverb as an authoritarian argument to strengthen his statements and opinions.

François Fillon, the former Prime Minister of France, criticizes the current President François Hollande in the discourse of January 14, 2014 published in French magazine "20 minutes". François Fillon complains about rising taxes and changing the limit for retirement age to 62. He claims that he believes in the words of the French President, but the reality is quite troubling. François Fillon uses the proverb originated from Japan "You can't clear away the fog with the fan" (on ne chasse pas le brouillard avec un éventail). In this case the proverb is also used as a way of strengthening the argument, comparing between the way out of the difficult processes occurring in France and clearing away the fog with the fan. François Fillon even finds it impossible to get out of this situation. With the help of this proverb, he tries to reinforce the opinions expressed by him in the same discourse.

First of all, usage of proverbs by oppositionist or current politicians is a characteristic feature of political discourses of both languages:

1. As one of the argumentative techniques

2. As one of the best tool of persuasion

3. To build strong emotional discourse

4. To illustrate a better future of the country

5. To show the attitude towards the opposition or the future

The analysis has revealed the following differences:

1. The proverbs used in Georgian discourses have rarely been used as the title of the article.

2. Almost all the proverbs found in the French articles were used as titles.

3. The proverbs in Georgian discourses mainly consisted of proverbs that were popular in Georgian society.

4. The proverbs in French discourses had purely French origin, as well as a foreign one.

\section{CONCLUSION}

As a general conclusion, we can say that the use of proverbs as an effective tool of persuasion in political discourse is effective when it is persuasive and at the same time causes an emotional response. The meaning of the proverb is much clearer in the language of persuasion. It can be said that proverb is one of the main tools of persuasion in the political language. From a political point of view, the credibility of the speaker/narrator is important. Whether or not the speaker is going to believe it is probably a whole socio-psychological complex chain.

It is quite relevant to use proverbs known to the society. Politicians use them to strengthen their opinions and positions. Proverbs are one of the key argumentative techniques of political discourses for persuading the audience.

\section{REFERENCES}

[1] Amossy, R. (2000). L'argumentation dans le discours. Paris: Nathan Université.

[2] Annonces de François Hollande: François Fillon veut bien "prendre le président au mot" mais ne "s'en satisfera pas". (15/01/14). https://www.20minutes.fr/societe/1273483-20140114-hollande-tient-troisiem-conference-presse-tumulte-vie-privee (accessed 12/01/2019).

[3] Anscombre, J. C. (2000). La parole proverbiale. Paris: Larousse.

[4] Anscombre, J. C. (1994). Proverbes et formes proverbiales: valeur évidentielle et argumentative. Langue Française 102, $95-$ 107.

[5] Après l'Elysée "les risques d'effort psychologiques sont réels". (12/05/2017). www.revuedesdeux mondes .fr/tag/francoishollande/ (accessed 03/05/2018).

[6] Archil Talakvadze on possible alterations to the Labour Code-Measure thrice and cut once (24/10/2019). 1TV.ge/news/archiltalakvadze-mnishvnelovani-kanonebi-gavlenis (accessed 3.05.2018).

[7] Barley, N. (1972). A Structural Approach to the Proverb and Maxim with Special Reference to the Anglo-Saxon Corpus. Proverbium 23, 880-884.

[8] Baylon, G. (1996). Sociolinguistique, société, langue et discours. Paris: Nathan.

[9] Charaudeau, P. (2005). Le discours politique. Les masques du pouvoir. Paris: Vuibert.

[10] Crise: Sarkozy se répète à Toulon. (2011). https://lelab.europe1.fr/crise-sarkozy-se-repete-a-toulon-168 (accessed 31/01/2020).

[11] Déclaration de Jacques Chirac dissolution de l'Assemblée Nationale. (21.04.1997). www.ina.fr/video/CAB97104491 (accessed 03/03/2018).

[12] Dimitri Kumsishvili on governmental changes-Easter and tomorrow. (17.11.2016). www.interpressnews.ge/politika /406810dimitri-qumsishvili-samthavrobo.(accessed 03/05/2019).

[13] Interwiew de Jacques Chirac, President of France, in "Focus". (15/09/1997) (accessed 24/07/2017).

[14] Ivanishvili: Some grief is beneficial, I've never liked the zoo in those conditions (18/06/2015). http:/tbl.ge/3uh (accessed 05/02/2019).

[15] Kakha Kukava -How can we live in a country where one half of population stays home during elections and the other one will receive fifteen GEL (10/10/2018). 1TV.ge/news/kakha-kukava-rogor (accessed 03/05/2019).

[16] Kleiber, G. (2000). Sur le sens des proverbes. Langages 139, 39-58.

[17] [Krikmann, A. (1998). On the Relationships of the Rhetorical, Modal, Logical, and Syntactic Planes in Estonian Proverbs. Electronic Journal of Folklore. http://www.folklore.ee/folklore/autors/krik.htm pp.99-127 (accessed 3.02.2018).

[18] Kuusi, M. (1972). Towards an International Type-System of Proverbs. Helsinki: Suomalainen Tiedeakateemia. 
[19] Mamuka Katsitadze: Yesterday Subari's speech was shameful (13/05/2011). Netgazeti.ge/News/9851 (accessed 02/02/2019).

[20] Mieder, W. (1996). International proverb scholarship. Proverbium 13. 421-445.

[21] Mieder, W. (2014). Behold The Proverbs of a People: Proverbial wisdom in culture, Literature, and Politics. Jackson, MS: University of Mississippi Press.

[22] Mieder, W. (2004). Proverbs: A Handbook. Westport, Connecticut: Greenwood Press. (Reprint: New York: Peter Lang, 2012).

[23] Mieder, W. (1983). Proverbs Are Never Out of Season: Popular wisdom in the modern Age. New York: Oxford University Press.

[24] Mikheil Saakashvili: Our power is in the unity. (23/12/2012). www.iverioni.com.ge-3318-mikheil-saak ashvili-chvenidzala.(accessed 15/07/2018).

[25] Some grief is beneficial - Bidzina Ivanishvili (27/11/2019). https:/fortuna/post/zogi-chiri-margebelia-bidzina-ivanishvili (accessed 02/02/2019).

[26] Tamba, I. (2011). Sens figé: idiomes et proverbes. In Le figement linguistique: la parole entravée, textes réunis par J. C. Anscombre et S. Mejri, Paris H. Champion.

[27] Taylor, A. (1931). The Proverb. Cambridge, Mass: Harvard University Press.

[28] The number one in the list of the United National Movement, the Speaker of the Parliament of Georgia, Davit Bakradze addresses the supporter of the ruling party. (28/05/2011). Netgazeti.ge/news/16339 (accessed 05/02/2019).

Bela Glonti was born in Lanchxuti, Georgia, in 1984. She has M.A. degree in roman philology with distinction in2007. From 2009 to 2010 she has worked as French linguistics teacher at Ilia State University. In 2012 she was invited in Paris- Est University (Creteil, France) in the framework of TEMPUS project for scientific research about her PhD thesis. She is a member of the Francophone Regional Doctoral College of Central and Eastern Europe in the Humanities (CODFREURCOR). 